\title{
WAS ISRAEL A WESTERN PROJECT IN PALESTINE?
}

\section{Ibrahim KARATAŞ*}

\begin{abstract}
This study aims to ascertain the extent to which it was Western powers or Zionists that founded Israel. The study argues that Israel was established by Western powers, while not ignoring the partial but significant role of Zionists that sought for a Jewish homeland. The West needed a Jewish homeland in order to utilise Jewish wealth, while also keeping Jews away since they were disturbed by the presence of the Jewish community. On the other hand, the World Zionist Organisation, motivated by anti-Semitism and nationalism, pioneered the idea of a Jewish national home and tried to persuade Western leaders as to the viability of a homeland in Palestine. While Zionist lobbying was influential, it can hardly be argued that they would have founded Israel without the help and permission of Western states, and in particular, the British Empire. The study aims to reveal external roles in nation-building by analysing the case of Israel. Methodologically, both quantitative and qualitative researches were used.
\end{abstract}

KEYWORDS: Israel, Zionism, Mandate System, Palestine, Middle East.

\section{INTRODUCTION}

The State of Israel was founded in 1948 with UN Resolution 181 that partitioned the Mandate of Palestine into two states: Palestine and Israel. However, due to several wars fought between neighbouring Arab states and Israel that resulted in the defeat of the former, Israel occupied most of the Palestinian territories, thereby leaving only one single state (Israel) on the former mandate. Unlike other countries, as Israelis themselves accept, Israel does not accept multiculturalism and multi-ethnicity, recognising only Judaism as the official religion and Hebrew as the nation's language. Therefore, it has a religious and ethnical identity rather than a secular one. This identity shapes its domestic and foreign policies. With this in mind, the Israeli-Palestinian conflict continues through a continuous, lowintensity war due to the rejection of the Palestinian state and the basic rights of Palestinians. When looking at this issue from the Arab side, Israel's reluctance to withdraw from the occupied lands and non-acceptance of a permanent solution, most probably due to its strength against its adversary, as well as foreign support for the Israeli state, have worsened the conflict and do not give a hope for a likely solution.

\footnotetext{
* Assistant Professor of International Relations, Istinye University Turkey, ibratas@gmail.com, ORCID: 0000-0002-2125-1840.
} 
Many scholars, particularly those of Arab origin, find the root problem of the conflict in the Western support of Israel. To them, Israel was a Western project that aimed to create a Jewish state, through which they can control the 'Middle East' and its resources. Indeed, plans for founding a Jewish state go back to the late 18th century. Since then, two big colonial powers, France and the British Empire, as well as the United States welcomed a Jewish state in the Palestine, which is claimed as the Biblical home of the Jews (Zanotti, 2018: 3). There is plenty of evidence indicating that there would not be a country called Israel had there not been Western affirmation. On the other hand, the efforts of Jewish businessmen like the Rothschilds and NGOs such the World Zionist Organisation (WZO) should not be underestimated. For a project to come into being, the decisive factor may include luck, common interests, conjuncture, or hard work. In Israel's case, since belligerents were in need of finance to maintain their wars, they attempted to take rich Jews to their side in return for a homeland in Palestine. While this study does not ignore Zionist efforts for founding Israel, it argues that Israel was founded by the West, as Jewish economic power alone was not sufficient to create a state. What is more, Jews lacked hard power. Studies analysed below also support the view that Zionists could not have founded Israel had the British Empire and other powers not allowed them to do so. Moreover, the lack of Arab institutions, weak cohesion, poor organisation, attempts to annex Palestinian state and wrong policies, also facilitated the foundation of Israel. On the other hand, even if Israel was the fruit of Western colonialism, it should be noted that the Jewish state cannot survive without Western support, and in particular, through US aid. The study is expected to contribute to the literature with its theory that: 1- Jewish hatred of the West, 2- exploitation of Jewish wealth, and 3-Zionism led to the foundation of Israel. In other words, a nation can be built by an ethnic group, but in Israel's case, Gentile-hating Jews helped them to build a homeland for themselves. Therefore, national awareness of the perceived need for a new nation, along with others who are convinced of the same, can found a nation-state.

Regarding the method used for writing this article, the views of those claiming that Israel is a Western project and those attributing it to the efforts of Zionists in literature were compared. While the Palestinian perspective was mainly omitted, an interview was carried out with a Palestinian Professor. This study will first focus on the role of Western powers in creating a home for Jewish people. Second, it will examine Jews' own efforts to found their states in Palestine. Finally, an authorial assessment of the discussion will be made.

\section{THE WESTERN SUPPORT FOR A JEWISH HOMELAND}

Jews lived in diaspora for 2000 years after the Babylonian exile and dreamed of returning back to Palestine, which they claim was promised to them by God. Yet their wishes remained as dreams until the late 19th century when the WZO was founded. WZO's main goal was to found a homeland for the Jewish people 
spreading all over the world. It was a purely nationalist movement rather than a religious one, but it used Biblical promises as one of their central tenets to attract Jews and gain their support. In the Old Testament, it is stated that "I will establish your borders from the Red Sea to the Mediterranean Sea, and from the desert to the Euphrates River. I will give into your hands the people who live in the land, and you will drive them out before you" (Exodus, 23:31). Thus, as per the verse, the land is promised to Abraham and his descendants. Yet Arabs have countered Jewish views of the Biblical promise, arguing that if these lands were given to Abraham, then Arabs should have the same claims for the land as they are Abraham's sons too.

Leaving aside the Biblical aspect, establishing a national home for Jewish people in Palestine seemed to be included in the colonial agenda for the first time by Napoleon of France in 1799. He aimed to obtain the loyalty of Jews, use Jews as his agents throughout the world, by rebuilding the temple in Jerusalem, enabling Jews to return to Palestine and to pose a threat to the British in the region (Kayyali, 1977: 98). After Napoleon sieged Acre in 1799, French newspaper Le Moniteur Universel wrote that Napoleon Bonaparte had called all Jews in Africa and Asia to gather under his flag in order to rebuild the old temple in Jerusalem (Glatt, 2016). However, since Napoleon was defeated, his plan was not realised. Aside from France, Russia and Germany also showed their interest in Palestine, and in view of this, the British were alarmed and looked for a way to influence Palestinian territories (El-Awaisi and Yiğit, 2020: 1; Ediz, 2019: 103). The British should not have been as late as it was in responding because Russia had already been in Palestine with the excuse of protecting orthodox minorities, while France was also there to defend the rights of Catholics (Schölch, 1992: 41). The British Empire were of the Protestant faith, which was almost non-existent in Palestine. However, it was not difficult for the British government to find a reason to become involved in Palestine. The 'gentile Zionists' of Britain and some Protestant groups were already conducting visits to Al-Quds and pressuring the government for the 'restoration of the Jews' to initiate a Jewish state under Ottoman rule. For example, in 1840, British Foreign Minister Lord Palmerston wrote a letter to Lord Ponsonby, British Ambassador to the Ottoman Empire, in which he asked the ambassador to convince the Sultan that if the dispersed Jews living across Europe were encouraged to return to Palestine, the Ottoman State would benefit from the wealth of Jews.

In the 1840s, British people with various professions such as politicians, journalists, clerics, and colonial officers began to call for a Jewish homeland more vocally (Schölch, 1992: 45). As Saylor (2011: 4-12) lists: in 1839, the Church of Scotland sent a committee to Palestine to learn the conditions of Jews and publish a memorandum asking the restoration of the old Jewish home; in 1840, the British government reportedly considered restoration; again in 1840, several lords announced their support for Jews' return to Palestine; and in 1877, British Prime Minister Benjamin Disraeli wrote that Jews would become a nation in Palestine 
under the British guidance within fifty years. To protect its strategic and economic interests, the British government turned religious-based demands into an opportunity and opened a consulate in the holy city of Al-Quds in 1838 (Hyamson, 1917). Palestine was a buffer to Egypt and a gateway to Iraq, and more importantly, was strategic in its location to protect India, as well as to control trade in Suez Canal, shortening the route between London and India at least 4.000 miles (Lobell, 2010: 14). London looked favourably on the idea of locating Jews to Palestine, since it thought the latter would also be a barrier to the Egyptian ruler Muhammad Ali's ambitions (Schölch, 1992: 45). A Jewish homeland was a good idea for the British because they were well aware that if another country controlled this cordon sanitaire, it could cut the British connection with India (Mathew, 2013). Thus, it eventually occupied Egypt in 1882 and became more influential in Palestine.

There was also US support for a Jewish state in the 19th century. In the early 1800s, American President John Adams stated that he believed in the rebuilding of Judea as an independent country. In addition, Abraham Lincoln also declared his support for a Jewish national home in Palestine. When Russians began oppressing Jews in late 1800s, top American bureaucrats called for the giving back of Palestine to Jews (Jewish Virtual Library, 2017). What is common for the French, British and Americans regarding their views about a Jewish homeland is that they all refer to the Biblical home of Jews as being Palestine. In addition, there were Christian Zionists that lobbied for a Jewish state. Indeed, the support stemming from faith was crucial for a Jewish state. Protestant Brits and Americans read the Bible in the original Hebrew and were therefore more influenced by the Old Testament. In addition, the study of Hebrew was compulsory in American universities, including Harvard, for a long time (Rynhold, 2015: 4). What is more, dispensationalist Evangelicals believe that the gathering of Jews in Israel is a prerequisite for the coming of Jesus. Evangelical support became higher and more influential in the course of time and shaped US foreign policy on Israel.

The late 19th century and early 20th century saw the crystallisation of Western support for a Jewish nation. Theodor Herzl mentions in his book in 1896 that he submitted a request for the colonisation of Cyprus and the Sinai Peninsula, which included El Arish, but the plan was refused by the British government (Herzl, 1896: 60). To appease Herzl, the British Colonial Secretary Chamberlain offered a $13.000 \mathrm{~km}^{2}$ area in Uganda for a Jewish colony. However, Herzl and other members of WZO rejected the proposal and focused only on Palestine. Herzl also mentions another alternative for Palestine: Argentina. Sponsored by Maurice de Hirsch, the plan was to create an autonomous region for Jewish migrants (Herzl, 1896: 96). However, the plan was not realised. In 1907, a report called Campbell-Bannerman Report openly asked for a Jewish state in Palestine. The report submitted in 1907 to British Prime Minister Sir Henry Campbell-Bannerman emphasised that a Jewish buffer state, which is friendly to Europe and hostile to its neighbours, must be established in Palestine (Bar-On and Adwan, 2006: 322). 
During the First World War, the British saw that Germany and Russia were attempting to gain the support of Jews to use their fiscal power. Germans and Russians were also in contact with American Jews to influence the American administration. Alarmed by the lobbying efforts of the other belligerents, the British contacted Jewish elites in America to push the US into the war on the side of the entente powers and for Russian Jews to keep Russia in war. As a gesture, they welcomed Zionist aspirations about founding a Jewish homeland in Palestine (Cleveland, 2018: 243).

Eventually, the British took Jews to their side and quickly began to award them with a nation-state via the Balfour Declaration, which reads " 1 - His Majesty's Government accepts the principle that Palestine should be reconstituted as the National Home of the Jewish People. 2- His Majesty's Government will use its best endeavours to secure the achievement of this objective and will discuss the necessary methods and means with the Zionist Organisation" (Köse, 2018: 55). As can be seen, there was a promise to the Zionist Organisation for a state while no mention of the future of the Palestinians. While Arabs feared that the Balfour Declaration would cause a large influx of Jews, the WZO was happy as it was their first great success. The Prime Minister, Lloyd George, also confessed his displeasure with the Palestinians by saying later that "We could not get in touch with the Palestinian Arabs as they were fighting against us" (Terry, 2017: 195). In addition, Churchill stated in one of his speeches that a Jewish state would be an advantage to the British Empire (Makovsky, 2007: 62). Moreover, US President Wilson's administration also endorsed the declaration in 1917. Further support of great powers can be seen in the League of Nations endorsement of the Balfour Declaration and making the reconstituting of a Jewish state an international obligation (Becker, 2011: 2).

Besides this, a 'national home' for Jews is mentioned in the terms of the Paris Peace Conference, endorsed by all signatories, as well as in the terms of the San Remo Conference, endorsed by allied powers (Hertz, 2008: 15). The allied powers of World War I (Britain, France, Italy, and Japan) not only accepted the declaration but also asked for its implementation (Bardaji, Steiner and Cohen, 2015). Moreover, as Khalidi (2006: 32) argues, the Mandate for Palestine was deliberately written by the British government to create a Jewish homeland and to exclude the Palestinians from self-determination. Indeed, the Palestinians are mentioned nowhere in the articles of the Mandate as a people, nor is the term 'self-determination' used in relation to them. Conversely, Article two and six of the Mandate clearly state that the Mandatory shall secure the establishment of the Jewish National Home (Eakin, 2011). Practices of the British rulers also indicate that they were enabling the establishment of Jewish para-state institutions. While Jews had the self-governing institutions that a formal state had, the Palestinians were mainly governed by the local British authority. 
In furthering the aim of self-governance, allowing new waves of migration and land allocation and purchasing strengthened the position of Jews and assisted them to take more steps toward an independent Israeli state. While 76,400 Jewish migrants came to Palestine from Europe in the first ten years of the mandate, the total number of Jews increased almost ten times until 1948 (Hadavi, 1957). In addition, the British mandate allowed Jews to buy miri (state lands) and Mawat (an Ottoman term meaning uncultivated wasteland far from populated areas). While Zionists claim that Jews bought lands from Palestinians, Saleh (2020: 4-7) stresses that only less than $1 \%$ of Palestinian lands were bought from Palestinian Arabs during the Mandate period. Regarding the rest of the lands, while feudal landlords from outside Palestine (mainly Lebanese) sold 625,000 dunams to Jews, the local British authority granted 300,000 dunams and sold 220,000 dunams to them with a nominal fee. These figures may be contested by Zionists, but a United Nations report prepared in 1980 confirms Saleh's claims (United Nations, 1980). Consequently, although Jews owned 2\% of land at the beginning of the Mandate period, the amount rose to around 6\% in 1947. Fischbach (2008) conversely claims that Jewish companies owned $20 \%$ of Palestine in 1948.

The British policy is seen as a facilitation of Jewish colonisation by many scholars. Forman and Kedar (2003: 123) quote from many Israeli scholars, who name it different terms such as 'dual colonialism' and 'non-formal colonialism'. As Al-Hizmawi asserts, the British were not mediating, but helping Jews for nationbuilding against poor Palestinians (in Forman and Kedar, 2003: 502). For example, the British government formed the Peel Commission that finally proposed the partition of Palestine, further legitimising the Jewish state thanks to Zionist lobby efforts (Mayamey, 2010: 13). Although the offer of the Commission was rejected by the government, the partition decision of the UN was inspired by it. In 1947, the UN General Assembly accepted Resolution 181 for the partition of Palestine into two states: one Arab and the other Jewish. As per the decision, the Palestinians, who were a majority at that time, would take $44 \%$ of the land, while the Israeli state of Jews, who were a small minority at that time, would possess the remaining 56\%. The reason for giving more land to Israel was to let it absorb new immigration waves, but the given lands were not of a predominantly Jewish population. The British left Palestine, and Israeli leaders declared independence, in May 15, 1948. The United States recognised Israel minutes after proclamation, followed by the Soviet Union and other countries.

While the US is the first de facto recogniser of Israel, the first de jure recognising country is the Soviet Union (Kramer, 2017: 3). Regarding American support, one year before independence, the US administration had supported "The Partition Plan" in late 1947, and President Truman and the Congress had welcomed the migration of more Jews (Al Sarhan, 2017: 462). It was Truman that played the decisive role for the independence of Israel. Some authors even argue that the Israeli State could not have survived without Truman's support in its first 
years. According to Kramer (2017: 2), when Truman was introduced to a Jewish audience after his presidency in 1953, he called himself Cyrus, the ancient Persian king that helped Jews to return back to Jerusalem from the Babylonian exile. In fact, some of Truman's close accomplices were against an independent Jewish state. For example, Foreign Minister George Marshall had warned Truman not to recognise Israel or, otherwise, he would not work for Truman's re-election (Oren, 2008: 124). However, Truman, whose closest friend was a Jew, neglected all criticisms and warnings, and recognised Israel.

Regarding the Soviet Union's attitude towards the foundation of Israel, the leader of the Iron Maiden bloc recognised the new state shortly after the US recognition. Israel was a state of Jewish immigrants, most of whom came from Russia and Eastern Europe. One of the reasons of the immigration were the pogroms directed against the Jews there. Therefore, Jews were not on good terms with the Russians. Moreover, the Israeli state posited itself in the capitalist bloc, i.e. opposite to the Soviet Union. On the other hand, the Soviets allied with the Arabs, the archenemies of Israel. Based on these facts, one may think that the Soviet Union should have opposed the independence of Israel. However, new revelations have proven that Stalin staunchly supported the foundation of the Jewish state. According to Johnson (1998), Soviet leader Joseph Stalin was the founding father of Israel although he hated Jews and Zionism. He knew that the only way to undermine the British influence in the Middle East was to support Jews instead of Arabs (Katz, 1998: 3). Thus, he asked the Czech government to sell weapons to Israel, a turning point for the Arab-Israeli War of 1948. When Gromyko, Soviet ambassador to the UN, said in 1947 that "The Soviet Union would still prefer a single Arab-Jewish state with equal rights for the Jews and Arabs. But if this (is) impossible to implement there was a justifiable alternative: the partition of Palestine into two independent single states, one Jewish and one Arab", Israeli envoys shocked (Kramer, 2017: 5). From this speech onwards, Israelis believed that their country would be recognised globally. Israel's first ambassador to the UN, Abba Eban, once said that without Soviet arms and a vote in favour of partition, Israel could not have come into being (Kramer, 2017: 5).

Besides Western support for a Jewish state, Western hatred of Jews might also be a factor for its establishment. In Germany, Jews were unwanted people by the Nazi administration. In 1933, the Haavara Agreement was signed by Nazi Germany and German Zionists, making migration of 60,000 Jews to Palestine possible. In addition, other Jews, whether voluntarily or by escaping from Nazis, migrated to Palestine. Migration from Eastern Europe and Russia was also continuing. On the other hand, besides torture, Zionist groups argue that Nazis killed six million Jews, a number that must be clarified as it is not historically proven. Yet many scholars argue that the Holocaust was persuasive for other countries to support a Jewish state. Through this support, they consoled their conscience and fulfilled their humanitarian duty against Jews. According to Kleinman (2002), it was the Holocaust that swayed world opinion for the UN 
approval of the State of Israel. In addition, since Jews were not assimilated in the countries they lived, there were prejudices, discriminations, defamation and hatred against them. The exclusionary behaviours against Jews even turned into pogroms on several occasions long before the Holocaust. It was clear that Jews were an unwanted community in European societies. Therefore, when a Jewish home in Palestine appeared on the agenda, many states saw it as an opportunity to rid themselves of their Jewish population. Hence, if Jews decided to immigrate to Palestine, they would not oppose the migration of Jews to Palestine, and indeed they did not. For example, Hitler made a deal with David Ben Gurion called the 'transfer agreement' that permitted Jews to migrate to Palestine in exchange for their properties. Nazi Germany also tried to forcibly send Jews to Madagascar in 1940 (Browning, 2004: 81). Besides Germany, Italian Fascists proposed a Jewish self-governing territory in northeast Ethiopia (Time, 1938). Stalin also tried to gather Jews in far eastern territories of Russia in a Jewish autonomous oblast called Birobidzhan (Rosen, 2004). There were more attempts to create an autonomous Jewish homeland in various parts of the world (Japan, the US, Tasmania, Guyana, etc.) However, Jews were reluctant to leave Europe until they incurred the massacre in World War II. It should be noted here that the people of the home countries in which they lived hated Jewish wealth, Jews' influence in economy, politics, culture and social life and their resistance to assimilation. In addition, Jews were accused of having a role in the slaughter of 20 million Soviet citizens under Bolshevist ideology (MacDonald, 2007: 38). Therefore, a Jewish country would not be opposable by locals.

\section{ZIONIST EFFORTS FOR ESTABLISHING THE STATE OF ISRAEL}

The previous section examined the Western effect on the foundation of the State of Israel. Although the support of the West was incontrovertible, it would be misleading to ignore other factors that led to the creation of a Jewish state in Palestine. First, the WZO was established solely for the goal of founding of a Jewish state. Second, Jews as a people were rich, generally educated and qualified people with enormous wealth that would enable them to reach their goals. Third, perhaps not as a people but individually, and as small communities in various countries of Europe, Jews were involved in colonisation, industrial revolution and ideological clashes. They were quite powerful, but their power was divided. Hence, the only way for them to realise their goals was to unite, organise and centralise their power and establish a network among Jews, which was to be independent of borders.

It was the WZO that initiated and organised Jewish movement for creating a national home in Palestine. The WZO was founded by Theodor Herzl and his colleagues at the First Zionist Congress convened in Basel in 1897. The goal of the organisation was stated as establishing a legal home in Eretz Israel (Palestine) (Knesset, 2008). Thus, one of the main duties of Zionists became the diverting of Jews to Palestine. In fact, the late 1800 s witnessed Jewish migration from Eastern 
Europe to Western Europe due to anti-Semitic pogroms happening in Russia in 1881 (Kayyali, 1997: 103). However, Jews were not welcomed in the new destinations, further increasing anti-Semitist sentiments. Therefore, the WZO and Rothschilds began to deal with migration and encouraged Jews to settle in Palestine. Moreover, Zionism was argued to be a nationalist movement rather than being religious. Zionists as Jewish nationalists were influenced by nationalist movements in Europe in the 19th century. Many members of WZO had nothing to do with religion. However, they wielded Biblical promises in order to justify Zionist ideology and attract Jews. Yet, it can still be argued that religion was a crucial factor in Zionist ideology (see evidence below). In addition, what was helping them boost Jewish nationalism was anti-Semitism in Europe. The more antiSemitism increased, the more Zionism became popular among Jews. Therefore, anti-Semitism became a useful tool for Zionists in order to take root and grow among Jewish communities.

As soon as the WZO was founded, Theodor Herzl started to seek the support of great powers for a Jewish state in Palestine. He travelled to Istanbul and Palestine to meet the Sultan of Ottoman Empire and Wilhelm II of Germany (Israel Information Center, 2004: 3). However, Herzl failed to persuade them, although he supposedly offered the Sultan to pay the entire foreign debt of the Ottoman Empire. He then turned to Britain and visited top British officials including Colonial Secretary Joseph Chamberlain with the help of Lord Rothschild. Herzl returned with the British proposal of an autonomous Jewish region in Uganda (in today's Eldoret region of Kenya), but he and other members of the Zionist Congress rejected the idea (Saylor, 2011: 7). Refusal of Uganda as a homeland and the insistence on Palestine are regarded as a clue that religion was a part of Zionist ideology since they refused the British proposal and insisted on Muslim Arabpopulated Palestine, which was difficult to secede from the Ottoman Empire.

Whether religious or national, the Zionist ideology was able to obtain support from the British Empire as Palestine was to be occupied by the colonial power during the World War I. In 1917, British Foreign Secretary Balfour wrote a letter to Lord Baron de Rothschild that they accepted the idea of a Jewish national home in Palestine. This may be regarded as a grant from the British Empire, or a decision that is in the interest of the British, but they might not have given such a decision had there not been rich and influential Jews like Lord Rothschild and Jewish intellectuals. For example, Chaim Weizzmann and Nahum Sokolov of WZO visited Britain many times to present their projects for Palestine. What is more, when they wished to meet cabinet members, Jewish minister Herbert Samuel assisted them to do so. Besides that, Samuel explained to other cabinet members the necessity for a Jewish homeland in Palestine (Samuel, 1915). Overall, ignoring the efforts of the leading Jewish figures for the Balfour Declaration would be misleading. Indeed, Jewish elites lobbied and pressured the British before and after the Balfour Declaration. In 1877, British Prime Minister Benjamin Disraeli was dreaming of a Jewish state under British protection. Another Jew, Sir Moses Haim 
Montefiore, visited Jerusalem seven times and worked for its development (Saylor, 2011: 5). In addition, Louis D. Brandeis, an influential American Zionist, pressured President Wilson to accept the Balfour Declaration (Al Sarhan, 2017: 461). Moreover, Truman's decision to recognise Israel was partly due to his best friend, who was a Jew (Oren, 2008: 124). Furthermore, Chaim Weizzmann was in contact with the Soviet Union's ambassador to the United Kingdom, who was also a Jew (Kramer, 2017: 11). Therefore, Jewish lobbyism was active long before the foundation of Israel, and it was surrounding policymakers of great powers to persuade them accept their request.

Another characteristic of Jews was that they were wealthier than other communities in the countries in which they lived. According to Windolf (2009: 15), who researched Jewish wealth between 1900 and 1933, while the number of Jews was $1 \%$ in German population, $25 \%$ of members of the core corporate network had a Jewish background. In the United States, $4.3 \%$ of top managers of large corporations were Jewish. The situation in the United Kingdom was no different than in the US and Germany. Regarding the Rothschild family that funded the WZO and the Jewish migration to Palestine, they were the richest family of the European continent and were called the Central Bank of Europe (Cook, 2019). In addition, as stated above, what was influencing British thinking about the Jews was their wealth, a factor that convinced politicians like Churchill to give them a home in Palestine. Moreover, when Theodor Herzl wanted Palestine from Ottoman Sultan, he offered to pay the Empire's whole debt to Europe. This fact shows that, fiscally, Jewish diaspora was more powerful than the Ottoman Empire.

Using this wealth, land was bought by Jews in Palestine in the first half of the 2oth century and thousands of Jews migrated to their future state. With the establishment of the Palestine Jewish Colonisation Association (PICA) by Baron Edmond de Rothschild, who became the largest Jewish landowner in Palestine for a while, more land was bought. According to Halbrook (1981: 368), while Jewish landownership was initially 22.500 acres (0.09\%) in 1882, it became 225.000 acres $(0.8 \%)$ in $1900,865.000$ acres (3.2\%) in 1927, 1.231 .000 acres (4.7\%) in 1936 and 1.734 .000 acres (6.6\%) in 1947. Some of the land was bought from local Arabs with quite high prices with much of this land allocated by the British. Parallel to land acquisition, the number of migrants rose year by year. The first wave of European Jewish migrants arrived in Palestine in 1882. According to Ottoman records, the Palestinian population in 1878 was 462,465 inhabitants, of whom 15,011 were Jews. By 1914, the Jewish population rose to 60,000, while Arab inhabitants numbered 683,000 (Beinin and Hajjar, 2014: 2). According to the census of 1931, the Jewish population was 174,600 (17\%), while the rest, including non-Arabs was 861.200. Finally, one year before the establishment of Israel, i.e. in 1947, the Mandate Authority estimated that there were 589,341 (31\%) Jewish inhabitants and 1,908,775 other people, mainly Arabs, in Palestine (Halbrook, 1981: 365). It is obvious that without Jewish institutions, migration could not be organised, and 
migrants might not have found a shelter in Palestine. In other words, land purchasing and migration was an organised policy steered by legal and illegal Jewish NGOs.

On the other hand, Arab states were in conflict with each other about the future of Arab Palestine. According to Khader (2017: 23), Transjordan Hashemites tried to annex Arab Palestine and made negotiations with Israelis about their plan. However, Egypt and Syria opposed this idea and worked hard to prevent it. In return, Transjordan was concocting Arab League's plans about the Palestinian state. Actually, Egypt, Syria, Transjordan and Iraq sent troops to Palestine during the first Arab-Israeli War of 1948, but since they were less equipped and their troops were poorly trained, they were defeated. As a result, Israel increased the percentage of its territory from $56 \%$ to $77 \%$. Arab armies were defeated in the following wars as well, causing more occupation of Palestinian lands. In fact, Palestine was not of extraordinary concern of Arab states. One reason is that they were struggling to manage their own domestic and external threats. Even now, many Arab countries still do not enjoy stability since independence. Therefore, Palestine was/ is a secondary case. Second, in distancing themselves, Arab regimes were reluctant to counter Israel for the lands of their 'cousins'. Third, as mentioned above, they preferred to annex Palestine instead of fighting for its independence. In other words, they wanted to see Palestine as one of their provinces rather than an independent state. However, obviously the occupation of Palestine by Israel was not something they favoured, either. On the other hand, Zionists also did not want an independent Palestine. According to Mearsheimer and Walt (2006: 10), the Zionist leadership never accepted a bi-national state or partition, basing their arguments on David Ben-Gurion's statement that Zionists will abolish the Palestinian state and expand to the whole Palestine after the formation of the Jewish state. While they evacuated Arabs from 'Israeli' state with 'Plan Delat', they also occupied Arab Palestine as soon as the first Arab-Israeli War began.

Meanwhile, while the Arab Streets were full of Israeli hatred, not all Western leaders were philo-Semitists. Some policymakers did not have favourable views about Jews, but they were too intimidated to disclose them in public. According to Kayyali (1997: 101), as White House tapes revealed, Richard Nixon did not make good remarks about Jews. In addition, Truman's Foreign Secretary Marshall was against the recognition of Israel. Furthermore, Dwight Eisenhower vetoed weapons sales to Israel and his Defence Secretary John Foster Dulles described Israel as "the millstone around our necks" and threatened to sanction it during the Suez Crisis of 1956 (Oren, 2008: 124). Moreover, Wilson had widespread prestige in the Arab World due to his ideas. Thus, he was reluctant to endorse the Balfour Declaration but could not stand against his Jewish friend's insistence (Al Sarhan, 2017: 461). Regarding Britain, it had impeded Jewish migration several times, e.g. through the issuance of a White Paper that halted migration. The Soviet Union was also not pro-Jewish but their strategic interests in the Middle East forced 
them to endorse Israeli independence. Otherwise, Stalin, known for being staunchly anti-Semitist, would not have recognised Israel.

Since the United Kingdom was not able to maintain its global imperialism after World War II, it was replaced by the US. Therefore, the Western bloc came under the leadership of the US government and made decisions on behalf of the rest of the West. Thus, the US approach to Israel almost meant a Western approach. In fact, Israel was not an indispensable country for the US or for the West until the Six-Day War. When Israel defeated Arabs in 1967, the US began to rely on Israel and supported it. As a result, it began to give aid to Israeli state in the form of cash or weapons, which still continues. According to Freilich (2017: 135), total US assistance to Israel from 1949 to 2016 was 125 billion USD and the amount will be around 170 billion USD by 2028 . The annual US aid is equal to $1 \%$ of Israel's GDP, $3 \%$ of its national budget, or $20 \%$ of its defence budget. The question here is whether Israel can live without US aid or not. It is clear that it can do without it even if it has to tighten its belt in areas like education, health, military, etc. Therefore, the U.S aid is not a sine qua non for Israel.

The support of the US, whether fiscal, military or any other type, is claimed to stem from the power of Jewish/Israeli lobby (Mast, 2014). No other interest groups in the US have been able to divert US foreign policy so successfully away from what American interests would otherwise require (Mearsheimer and Walt, 2006: 1). Thanks to the influence of the Israeli lobby, the US has always vetoed anti-Israel resolutions in the United Nations Security Council, given full diplomatic support, granted the largest military aid, ignored Israeli nuclear weapons, and so on. Israeli and American Jews have great impact on the Congress, media and academia through pressure, donations or by using lobby firms like AIPAC, ADL, JINSA, etc. There were occasions when 400 out of 435 congressional representatives, or 99 out of 100 senators supported Israel. Some of them openly said that their number one priority was Israel. However, American support for the security and serenity of Israel and spending billions of USD is questioned by some American scholars. They claim that although the US army fought in several wars in the Middle East, Israel did not give support to American troops. In addition, Israel stole sensitive classified data, did not obey US instructions and sold US military technology to China, indicating that it is not a loyal ally (Mearsheimer and Walt, 2006: 5-6). Moreover, absolute support of Israel has caused the growth of American hatred among Arab people. Therefore, US sacrifice for Israel, led to Arab opposition and attacks onto American forces. On the other hand, Chomsky (1991: 22) thinks that the power of the Jewish lobby is exaggerated and can easily become ineffective if American interests require otherwise.

Assuming for a while that the US no longer gives aid to Israel, can the latter survive without American aid? Articles published in Israeli and Jewish diaspora newspapers argue that Israel may suffer, but it may even be better for the country as an independent Israel will be forced to produce its indigenous weapons, 
thereby eventually will not feel the lack of American aid (Pfeffer, 2019). They also claim that Israel can ally with either Russia or China, or both. Professor Sami AlArian, a Palestinian scholar, said in an interview exclusive to this study that Israel can survive, but with great difficulty (Al-Arian, 2020). Given that Israel has an advanced defence industry and sophisticated weapons like atomic bombs, it can defend itself without foreign support unless there is a sudden destructive attack. However, the lack of US support will certainly force Israel to negotiate and give concessions to the Palestinians and other Arab states. When Israel is alone, it will not probably remain deaf to requests of the Arab street and it may compromise with its neighbours to ensure its security. However, currently, since it relies on US military, political, economic and diplomatic power, it does not need to step back. For instance, it would probably accept the two-state solution had there not been US support. Besides, US support is so vital that if Arab states such as the UAE, Bahrain, Egypt and Saudi Arabia are signing peace deals with Israel, it is not because they want to get closer to Tel Aviv but Washington. Overall, Israel would survive without the US aid and support, but it would have to give concessions and face more difficulties.

\section{ASSESSMENT ABOUT WHETHER ISRAEL IS A WESTERN OR ZIONIST PROJECT}

It can be assessed that Israel was created by the West due to several reasons. Before discussing them, it should be admitted that Jews had a role in founding Israel, though it was relatively small. Jewish wealth, qualified human power, the need for a national home to escape from anti-Semitic discrimination and pogroms and so forth, were all advantages of Zionists. Wolfshonn (1993) might be exaggerating when he says Israel was founded primarily due to social, political, economic and military achievements of Zionists, but he is still right to some extent. This is because a Jewish state was an existential matter for Zionists and they dedicated all their power towards its creation. The WZO, the efforts of Zionist individuals like Herzl and Weizzmann, donations of the Rothschilds, lobbying, the establishment of close relations with policymakers of great powers, forming militant groups in Palestine, organising and coordinating migration, purchasing lands, religious motives, nationalist sentiments, etc. all of these were self-created reasons by Jews to establish a Jewish state.

However, none of these factors were enough to establish a homeland in Palestine. Israel was established by Western countries led by the British Empire because, first, culturally, Judeo-Christian culture is the basic common point between the two. While their religions are quite close to each other, their lifestyles are even closer since most Jewish migrants came from Europe. A European might feel alien in an Arab country, but he/she may feel at home in 'Israel'. In addition, Evangelical Protestants believed what was written in the Old Testament and they aimed to help Jews to return back to their promised lands from the mid-180os onwards. Therefore, the establishment of Israel was deemed a religious duty by some Christians and particularly Christian Zionists. Second, 
Jewish wealth occupied the attention of Westerners. From Napoleon Bonaparte to Winston Churchill, Western leaders tried to utilise Jews' money and so offered a Jewish home for the sake of that money. Thus, Western powers indirectly traded Palestine to Jews for enormous capital. In other words, it was a commercial transaction. Third, Jewish hatred always existed in Europe and was reflected in anti-Semitic behaviour. From Eastern Europe to Western Europe, Jews were an unwanted community, whom Europeans thought unassimilable, controlling all aspects of life, and exploiting their resources. Such views even led to pogroms and finally Holocaust. Hence, they supported a Jewish state, to which Jews may migrate. Finally, the Jewish Holocaust might have hurt the conscience of Europeans and encouraged them to recognise Israel. Meanwhile, the rationale behind Russians' support for a Jewish home was not only their desire to get rid of Jews but also to break British influence in the 'Middle East'. Therefore, it was political rather than humanitarian.

On the other hand, besides Western and Zionist efforts, overlapping interests, suitable timing of establishment, e.g. post-Holocaust years and the beginning of the Cold War, weak rivals of Jews, namely Arabs, the lack of a Muslim protector state like the Ottoman Empire, and the clashing interests of the Western and Soviet bloc in the 'Middle East' were factors that helped the foundation of Israel without any Jewish involvement. In addition, Jews were never in a position to found their state without foreign support. First of all, Jews were divided not only geographically but also notionally. Not all Jews were supporting of the idea of an independent Jewish state. Those favouring a state were not comprising a big enough population that could achieve their goals. Also, as they were relocated with the permission of the British, they owe even the number of their population to the British. Second, Jews were strong in terms of soft power but quite weak in the context of hard power. They would not have founded Israel without the endorsement of the British government. Neither during the Ottoman era nor the British mandate would they have been able to secure a homeland by fighting. Hence, it can be argued that the foundation of Israel was all attributable to the support and permission of foreign powers.

\section{CONCLUSION}

This study attempted to ascertain whether Israel was a Western or Zionist project and has concluded that it was founded by the British Empire, backed by other Western powers. The West wished to keep Jewish wealth closer and Jews farther from themselves. The British Empire, France and even Germany tried to benefit from Jewish money in return for a permanent home for Jews in Palestine. In addition, they used Jews against each other due to clashing interests in the 'Middle East'. While the French failed against the British in terms of exploiting Jews, Soviet leader Stalin tried the same tactic by supporting the independence of Israel in 1948 so as to break British power in the region. On the other hand, Americans supported a Jewish homeland due to their sympathy towards Judaism 
and trust in Biblical claims about Palestine. Another factor that made Europeans support Israeli state was to purify society from Jews. Anti-Semitism was at its peak level in the 19th and the 2oth century, sometimes culminating in pogroms. Therefore, in line with this study's theory that a nation-state can be founded by its adversaries, they welcomed a national home for Jews, to which they could emigrate. Overall, a Jewish state was a strategic tool for the West rather than being a Western branch in the 'Middle East', at least before its independence.

On the other hand, the Jewish diaspora under the leadership of Zionists tried to found their own state in the lands from where they were expelled 2000 years earlier. While not all Jews supported the idea, rising anti-Semitism and the Holocaust convinced them of the necessity of a state. Zionists used all their assets to persuade the British Empire for a Jewish national home and to obtain the support of other countries for legitimacy. Eventually, by spending an enormous amount of money, lobbying, organising migration, forming militant groups and putting pressure on Western politicians, the State of Israel was founded. Therefore, their role in creating Israel should not be underestimated. However, their soft power was not adequate to found a state without the support of Western powers. Consequently, this study argues that Israel was founded in Palestine with the help and permission of Western powers. 


\section{BIBLIOGRAPHY}

Al-Arian, S. (2020, 5 November). Interview by Author [Personal interview], Istanbul.

Al Sarhan, A. S. (2017). United States Foreign Policy and the Middle East. Open Journal of Political Science, 7:454-472.

Bar-On, D., \& Adwan, S. (2006). The Prime Shared History Project: Peace-Building Under Fire'. In Educating Toward a Culture of Peace, Iram, Y.(ed.), pp. 309-323. Greenwich: Information Age Publishing.

Bardaji, R., Steiner, T. and Cohen, E. (2015). Israel: A Vital Asset of The West. Madrid: Friends of Israel Initiative.

Becker, T. (2011). The Claim for Recognition of Israel as a Jewish State. Washington: Washington Institute.

Beinin, J. and Hajjar, L. (2014). Palestine, Israel and The Arab-Israeli Conflict. https://web.stanford.edu/group/sper/images/Palestine-Israel_Primer_MERIP.pdf Accessed on 27.05. 2018.

Browning, C. (2004). The Origins of the Final Solution: The Evolution of Nazi Jewish Policy, September 1939-March 1942. Lincoln: University of Nebraska Press.

Chomsky, N. (1991). U. S. Foreign Policy in the Middle East. Cultural Critique, 19 (Autumn): 14-31.

Cleveland, W. (2008). A History of the Modern Middle East. In The Palestine Mandate and the Birth of the State of Israel, Cleveland, W. and Bunton, M. (Eds.), pp. 239-271. New York: Routledge.

Cook, J. (2019). A History of the Rothschild Family. https://www.investopedia.com/updates/history-rothschild-family, Accessed on 05.05.2019.

Eakin, M. (2011). British Policy in Mandate Palestine: Institution Building and the Thwarting of a Palestinian State. http://www.miftah.org/Doc/SpecialStudies/2011/britain.pdf, Accessed on 05.11.2020.

Ediz, i. (2019). A Neoclassical Realist Explanation of the Balfour Declaration and the Origins of the British Foreign Policy in Palestine. Tarih Incelemeleri Dergisi, 34(1): 99-122.

El-Awaisi, K. and Yiğit, E. (2020). Early Foreign Penetration in the Holy Land during the Late Ottoman Period: The Role of Britain. Journal of Islamicjerusalem Studies, 20(1): 1-18.

Fischbach, M. (2008). Jewish Property Claims against Arab Countries. New York: Columbia University Press.

Forman, G. and Kedar, A. (2003). Colonialism, Colonization, and Land Law in Mandate Palestine: The Zor al-Zarqa and Barrat Qisarya Land Disputes in Historical Perspective. Theoretical Inquiries in Law, 4(2): 491-539.

Freilich, C. D. (2017). Can Israel Survive Without America? Survival, 59(4):135-150.

Glatt, B. (2016). This Day in History: Napoleon in the Holy Land. https://www.jpost.com/Christian-News/This-day-in-history-Napoleon-in-the-HolyLand-446099 Accessed on 02.07.2019.

Hadavi, S. (1957). Land Ownership in Palestine. New York: The Palestine Arab Refugee Office.

Halbrook, S. P. (1981). The Alienation of a Homeland: How Palestine Became Israel. The Journal of Libertarian Studies, 5(4): 357-374.

Hertz, E. E. (2008). This Land is My Land. New York: Myths and Facts.

Herzl, T. (1896). The Jewish State. New York: Dover Publications.

Hyamson, A. M. (1917). British Projects for the Restoration of the Jews. Leeds: Petty \& Sons. Israel Information Center (2004). Herzl and Zionism. Jerusalem: Ahva Press. 
Jewish Virtual Library (2017). Roots of the U.S.-Israel Relationship. http://www.jewishvirtuallibrary.org/roots-of-the-u-s-israel-relationship. Accessed on 20.03.2018.

Johnson, P. (2012). Israel: The Miracle. https://israelseen.com/2012/04/26/paul-johnsonisraelthe-miracle/, Accessed on 03.05.2019.

Katz, S. (1998). Interdependence in U.S.-Israeli Relations. http://www.shmuelkatz.com/Articles/Interdependence_In_US_Israel_Relations.pdf, Accessed on 05.06.2019.

Kayyali, A. (1977). Zionism and Imperialism: The Historical Origins. Journal of Palestine Studies, 6(3): 98-112.

Khader, B. (2017). The Palestinian Question and the Arabs (1917-2017): Popular Support, Government Stakes. Barcelona: IEMED.

Khalidi, R. (2006). The Iron Cage: The Story of the Palestinian Struggle for Statehood. Boston: Beacon Press.

Kramer, M. (2017). Who Saved Israel in 1947? https://mosaicmagazine.com/essay/israelzionism/2017/11/who-saved-israel-in-1947/ Accessed on 12.06.2019.

Kleinman, T. (2002). Did the Holocaust Play a Role in the Establishment of the State of Israel? Santa Barbara: UCSB.

Knesset (2008). The World Zionist Organization. https://www.knesset.gov.il/lexicon/eng/wzo_eng.htm, Accessed on 07.06.2019.

Köse, i. (2018). The Lloyd George Government of the UK: Balfour Declaration the Promise for A National Home to Jews (1916-1920). Belleten, 82(294): 727-759.

Lobell, S. (2010). Structural Realism/Offensive and Defensive Realism. In Oxford Research Encyclopaedia of International Studies, pp. 6651-6669. Oxford: Oxford University Press.

MacDonald, K. (2007). The Israel Lobby: A Case Study in Jewish Influence-The Israel Lobby and US Foreign Policy. The Occidental Quarterly, 7(3):33-37.

Makovsky, M. (2017). Churchill's Promised Land: Zionism and Statecraft. New Haven and London: Yale University.

Mast, N. (2014). The Israel Lobby and US Policy in the Middle East: The Iraq War, The Egyptian Arab Spring, and Iran's Nuclear Program. Unpublished Honor Thesis, Carnegie Mellon University, Pittsburgh.

Mathew, W. (2013). The Balfour Declaration and the Palestine Mandate, 1917-1923: British Imperialist Imperatives. British Journal of Middle Eastern Studies, 40(3): 231-250.

Mayamey, B. (2010). Zionism: A Critical Account 1897-1948. The Development of Israel and the Exodus of Palestine from A "New Historian" Perspective. POLIS Journal, 4 (Winter):1-34.

Mearsheimer, J. \& Walt, S. (2006). The Israel Lobby and US Foreign Policy. Cambridge: John F. Kennedy School of Government Faculty Research Working Paper Series.

Oren, M. B. (2008). Israel is Now America's Closest Ally. https://www.wsj.com/articles/SB121011902390872015 Accessed on 10.05. 2019.

Rosen, A. (2004). Birobidzhan- The Almost Soviet Jewish Autonomous Region. http://www.jewishmag.com/75mag/birobidzhan/birobidzhan.htm, Accessed on 04.11.2020.

Rynhold, J. (2015). The Israel Paradox: The Arab-Israeli Conflict in American Political Culture. International Studies Association Annual Conference, New Orleans.

Saleh, M.M. (2020). Did Palestinians Sell Their Land? And Leave It the Jews? https://www.alzaytouna.net/wp-content/plugins/extrawatch-

pro/components/com_extrawatch/extrawatch.php?origin=frontend\&task=ajax\&acti 
on=download\&env=ExtraWatchWordpressEnv\&file=english/AcademicArticles/EPA MohsenSaleh_Pls-People-Land_5-20.pdf, Accessed on 09.11.2020.

Samuel, H. (1915). The Future of Palestine, a Memorandum to British Cabinet. Samuel Archives, St. Anthony's College, Oxford.

Saylor Academy (2011). History of Zionism. https://resources.saylor.org/wwwresources/archived/site/wpcontent/uploads/2011/06/History-of-Zionism.pdf. Accessed on 15.07.2019.

Schölch, A. (1992). Britain in Palestine, 1838-1882: The Roots of the Balfour Policy. Journal of Palestine Studies, 22(1): 39-56.

Terry, P. (2017). Britain in Palestine (1917-1948) - Occupation, the Palestine Mandate, and International Law. University of Bologna Law Review, 2(2): 187-251.

Time (1938). Religion: Jews' Luck. http://content.time.com/time/magazine/article/0,9171,760019,00.html, Accessed on 05.11.2020.

United Nations (1980). Acquisition of Land in Palestine. https://www.un.org/unispal/document/auto-insert-208638/, Accessed on 09.11.2020.

Windolf, P. (2009). Das Netzwerk der Jüdischen Wirtschaftselite: Deutschland (1914 1938). In Inklusion und Exklusion, Windolf, P. and Stichweh, R. (Eds.), pp. 275-302. Wiesbaden: VS-Verlag.

Wolffsohn, M. (1993). Eternal Guilt? Forty Years of German-Jewish-Israeli Relations. New York: University Press.

Zanotti, J. (2018). Israel: Background and US Relations. Washington: CRS. 